\title{
PELAKSANAAN PENINGKATAN KEPATUHAN PELAPORAN LAPORAN HARTA KEKAYAAN PENYELENGGARA NEGARA (LHKPN)
}

\author{
Yuniarty Veronika Ingnuan ${ }^{1}$, Mohamad Lutfi ${ }^{2}$ \\ ${ }^{1}$ STIE Muhammadiyah Jakarta, yuniartyveronika@gmail.com \\ ${ }^{2}$ STIE Muhammadiyah Jakarta, nita.lutfita@gmail.com
}

\begin{abstract}
ABSTRAK
Penelitian ini bertujuan untuk menguji dan menganalisa Pelaksanaan Peningkatan Kepatuhan Pelaporan Laporan Harta Kekayaan Penyelenggara Negara (LHKPN) di Lingkup Instansi Daerah pada Direktorat Pendaftaran dan Pemeriksaan LHKPN. Dalam penelitian ini penulis menggunakan metode analisis data Deskrptif Kualitatif dengan menggunakan model Analisis Interatif. Penulis menggunakan teknik Triangulasi untuk menguji keabsahan data yang telah diperoleh selama penelitian. Metode Sampling Purposive yaitu teknik penentuan sample dengan pertimbangan tertentu. Hasil peneltian membuktikan bahwa tingkat Kepatuhan Pelaporan LHKPN di Lingkup Instansi Daerah mengalami penurunan dari tahun 2016-2017. Prosentase tersebut masih bisa naik apabila didukung dengan adanya peran serta kesadaran Wajib Lapor untuk melaporkan harta kekayaannya dan komitmen Kepala Daerah/ Pimpinan Instansi terkait penerapan sanksi bagi wajib lapor yang tidak melaporkan LHKPN pada KPK. Selnjutnya tingkat Kepatuhan Pelaporan LHKPN di Lingkup Pemerintah Provinsi Kepulauan Bangka Belitung pada tahun 2017 mengalami kenaikan. Karena sejak awal Gubernur Pemerintah Provinsi Kepulauan Bangka Belitung sudah berkomitmen dalam rangka pencegahan korupsi salah satunya dengan pelaporan LHKPN dan mengeluarkan Peraturan Gubernur Kepulauan Bangka Belitung Nomor 56 Tahun 2017 tentang Pengelolaan Laporan Harta Kekayaan Penyelenggara Negara di Lingkungan Pemerintah Provinsi Kepulauan Bangka Belitung serta mengeluarkan Surat Edaran Nomor: 840/0098/VII/2018 pertanggal 3 April 2018 tentang penundaan pembayaran Tunjangan Perbaikan Penghasilan (TPP).
\end{abstract}

Kata Kunci : LHKPN, Lingkup Instansi Daerah pada Direktorat Pendaftaran dan Pemeriksaan LHKPN

\section{ABSTRACT}

This study aims to test and analyze the Implementation of Enhancing the Compliance of Reporting the Statutory Assets of State Assets (LHKPN) in the Scope of Regional Agencies at the Directorate of Registration and Examination of LHKPN. In this study the authors used a Qualitative Descriptive Data analysis method using the Interative Analysis model. The author uses the Triangulation technique to test the validity of the data that has been obtained during the study. 


\section{JURNAL EKOBIS: EKONOMI, BISNIS \& MANAJEMEN}

\section{Volume 8 Nomor 2 (2018)}

Purposive Sampling Method is a sample determination technique with certain considerations. The results of the research prove that the level of LHKPN Reporting Compliance in the Scope of Regional Agencies has decreased from 2016-2017. This percentage can still increase if it is supported by the role and awareness of the Obligatory Report to report their assets and the commitment of the Regional Head / Head of Institution related to the application of sanctions for compulsory reporting who do not report LHKPN to the KPK. The next level of LHKPN Reporting Compliance in the Bangka Belitung Islands Provincial Government in 2017 has increased. Because since the beginning the Governor of the Bangka Belitung Islands Provincial Government has committed in the framework of preventing corruption, one of them is by reporting the LHKPN and issuing the Bangka Belitung Islands Governor Regulation No. 56 of 2017 concerning Management of State Organizer Asset Management in the Province of Bangka Belitung Provincial Government and issuing Circular Number : 840/0098 / VII / 2018 dated April 3, 2018 concerning the delay in payment of the Income Improvement Allowance (TPP).

Keywords: LHKPN, Scope of Regional Agencies at the Directorate of Registration and Examination LHKPN

\section{PENDAHULUAN}

Sejarah singkat tentang lahirnya LHKPN berawal pada masa pemerintahan BJ Habibie. Dalam rangka mengatasi masalah korupsi, presiden mengeluarkan Keputusan Presiden Republik Indonesia Nomor 81 tahun 1999. Dalam keputusan itu dibahas tentang pembentukan Komisi Pemeriksa Kekayaan Penyelenggara Negara (KPKPN). KPKPN merupakan lembaga independen yang berfungsi mencegah praktek korupsi, kolusi, dan nepotisme dalam penyelenggara negara sesuai Kepres Nomor 127 Tahun 1999. Namun sejak Presiden Megawati Soekarno Putri mendirikan KPK melalui Undang- Undang Nomor 30 tahun 2002, pada tahun 2002 KPKPN kemudian dibubarkan. Sejak itu KPKPN menjadi bagian dari bidang pencegahan KPK dan lahirlah LHKPN. LHKPN memiliki dasar hukum, kewajiban Peyelenggara Negara untuk melaporkan harta kekayaan diatur dalam :

a. Undang-undang Nomor 28 Tahun 1999 tentang Penyelenggara Negara Yang Bersih dan Bebas Korupsi, Kolusi dan Nepotisme;

b. Undang-undang Nomor 30 Tahun 2002 tentang Komisi Pemberantasan Tindak Pidana Korupsi; dan

c. Keputusan Komisi Pemberantasan Korupsi Nomor: 07 tahun 2016 tentang Tata Cara Pendaftaran, Pemeriksaan dan Pengumuman Laporan Harta Kekayaan Penyelenggara Negara.

LHKPN adalah daftar seluruh harta kekayaan Penyelenggara Negara yang dituangkan di dalam formuir LHKPN yang ditetapkan oleh KPK. LHKPN tidak hanya mencakup harta seorang penyelenggara negara, namun juga keluarga inti seperti pasangan dan anak yang masih menjadi tanggungan, (Tim SPORA "Pengatar Laporan Harta Kekayaan Penyelenggara Negara" (LHKPN). Jakarta: Direktorat Dikyanmas Kedeputian Bidang Pencegahan Komisi Pemberantasan Korupsi, 2015). 


\section{JURNAL EKOBIS: EKONOMI, BISNIS \& MANAJEMEN}

\section{Volume 8 Nomor 2 (2018)}

Dalam rangka peningkatan Kepatuhan pelaporan LHKPN pada Direktorat Pendaftaran dan Pemeriksaan LHKPN, KPK membentuk Unit pengelola LHKPN dimasing-masing K/L/O/P. Ternyata masih banyak K/L/O/P masih rendah Tingkat Kepatuhan Pelaporan LHKPN pada Direktorat PP LHKPN.

Grafik 1: Tingkat Kepatuhan Pelaporan LHKPN dari Tahun 2001 s/d 2018

$$
\text { LHKPN Update } 30 \text { Juni } 2018
$$

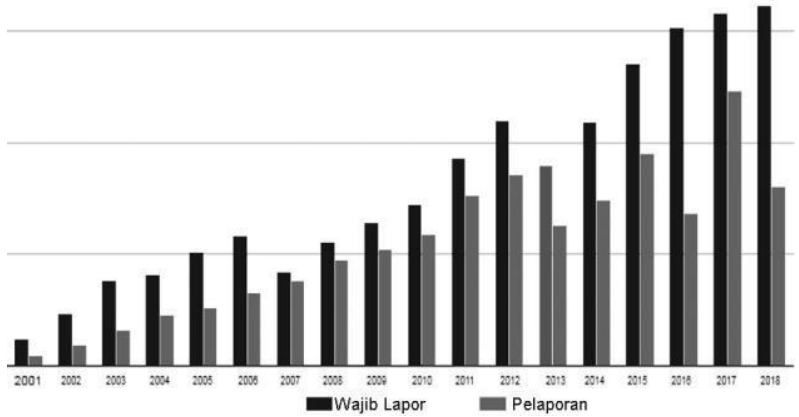

Direktur Pendaftaran dan Pemeriksaan LHKPN Bapak Cahya H. Harefa mengatakan bahwa tingkat kepatuhan pelaporan harta kekayaan Penyelenggara Negara secara Nasional sampai3 Agustus 2018 sekitar 52\% (Jakarta: ANTARA News, https://m.antaranews.com/berita/733053/ kpk-tingkat-lhkpn-nasional-52-persen, 3 Agustus 2018).

Berdasarkan uraian tersebut diatas penulis tertarik untuk meneliti tentang Pelaksanaan Peningkatan Kepatuhan Pelaporan Laporan Harta Kekayaan Penyelenggara Negara (LHKPN) di Lingkup Instansi Daerah pada Direktorat Pendaftaran dan Pemeriksaan LHKPN.

Tujuan dilakukan penelitian ini adalah sebagai berikut :

a. Untuk mengetahui upaya apa sajakah yang sudah dilakukan Direktorat PP LHKPN dalam

Pelaksanaan Peningkatan Kepatuhan Pelaporan LHKPN dilingkup Instansi Daerah.

b. Untuk mengetahui bagaimana hasil yang sudah dilakukan Direktorat PP LHKPN dalam

Pelaksanaan Peningkatan Kepatuhan Pelaporan LHKPN dilingkup Instansi Daerah.

c. Untuk mengetahui faktor pendukung dan penghambat Pelaksanaan Peningkatan Kepatuhan

Pelaporan LHKPN dilingkup Instansi Daerah pada Direktorat PP LHKPN.

\section{KAJIAN PUSTAKA}

Laporan Harta Kekayaan Penyelenggara Negara (LHKPN) pada prinsipnya merupakan laporan yang wajib disampaikan oleh Penyelenggara Negara mengenai harta kekayaan yang dimilikinya saat pertama kali menjabat, mutasi, promosi dan pensiun(hukum online.com:17-08-2012). 


\section{JURNAL EKOBIS: EKONOMI, BISNIS \& MANAJEMEN}

Volume 8 Nomor 2 (2018)

\section{Peraturan mengenai LHKPN}

1. Undang-Undang Nomor 28 Tahun 1999 tentang Penyelenggara Negara yang Bersih dan Bebas dari Korupsi, Kolusi dan Nepotisme.

2. Undang-Undang Nomor 30 Tahun 2002 tentang Komisi Pemberantasan Tindak Pidana Korupsi,dan

3. Peraturan Komisi Pemberantasan Korupsi Nomor : 07 Tahun 2016 tentang Tata Cara Pendaftaran, Pengumuman dan Pemeriksaan Harta Kekayaan Penyelenggara Negara (Ibid.)

\section{Kewajiban Penyelenggara Negara terkait LHKPN}

a. Bersedia diperiksa kekayaannya sebelum, selama dan sesudah menjabat (Pasal 5, Ayat 2, UU Nomor 28 tahun1999).

b. Melaporkan harta kekayaannnya pada saat pertama kali menjabat, mutasi, promosi dan pensiun.

c. Mengumumkan harta kekayaannya (Pasal 5, Ayat 3, ibid.)

Sanksi Tidak Memenuhi Kewajiban LHKPN Bagi Penyelenggara Negara yang tidak memenuhi kewajiban LHKPN sebagaimana diatur dalam Undang-Undang Nomor 28 Tahun 1999, maka berdasarkan Pasal 20 undang-undang yang sama akan dikenakan sanksi administratif sesuai dengan perudang-undangan yang berlaku (Ibid.)

\section{Pengertian Kepatuhan (Compliance Theory)}

Kepatuhan berasal dari kata patuh, menurut Kamus Umum Bahasa Indonesia, patuh artinya suka dan taat kepada perintah atau aturan, dan berdisiplin. Kepatuhan berarti sifat patuh, taat, tunduk pada ajaran atau peraturan. Kepatuhan sesuai yang didefinikan oleh Taylor (2014:266) adalah "memenuhi permintaan orang lain, didefinikan sebagai suatu tindakan atau perbuatan yang dilakukan berdasarkan keinginan orang lain atau melakukan apa-apa yang diminta oleh orang lain, kepatuhan mengacu pada perilaku yang terjadi sebagai respon terhadap permintaan langsung dan berasal dari pihak lain”.

Menurut Shaw (2010:25-26), kepatuhan berhubungan dengan harga diri sesorang di mata orang lain. Orang yang telah memiliki konsep bahwa dirinya adalah orang yang pemurah, akan menjadi malu apabila dia menolak memberikan sesuatu ketika orang lain meminta sesuatu padanya. Kebebasan untuk bersikap, juga seringkali mendorong orang untuk mengikuti kemauan orang lain.

Berdasaran beberapa uraian diatas, maka dapat ditarik kesimpulan bahwa kepatuhan terjadi ketika ketaatan semua aktivitas sesuai dengan kebijakan, aturan, ketentuan dan undangundang yang berlaku. Sedangkan kepatuhan lebih pada keluhuran budi pimpinan dalam mengambil keputusan.Jika melanggar kepatutan belum tentu melanggar kepatuhan.

\section{METODE PENELITIAN}

Penelitian ini dilakukan dengan menggunakan metode data deskriptif kualitatif dengan menggunakan model analisis interaktif (interactive model of analysis). Sedangkan jenis data 


\section{JURNAL EKOBIS: EKONOMI, BISNIS \& MANAJEMEN}

\section{Volume 8 Nomor 2 (2018)}

yang digunakan adalah data kualitatif. Teknik pengumpulan data yang digunakan dalam penelitian ini adalah Studi Kepustakaan, Internet research, Observasi, Wawancara.

Didalam mendapatkan responden penulis menggunakan teknik Sampling Purposive yaitu teknik penentuan sample dengan pertimbangan tertentu. Penulis memilih teknik ini karena menganggap bahwa subjek dan objek yang akan diteliti lebih cocok menggunakan teknik ini. Berdasarkan penjelasan di atas, sesuai dengan tema penelitian yang diusung oleh penulis yaitu pelaksanaan peningkatan kepatuhan pelaporan LHKPN pada lingkup Instansi Daerah pada Direktorat Pendaftaran dan Pemeriksaan LHKPN, maka sampel untuk sumber datanya harus orang yang ahli dalam bidang peningkatan kepatuhan pelaporan LHKPN.

Penentuan sample dalam penelitian kualitatif (naturalistik) sangat berbeda dengan penentuan sample dalam penelitian konvensional (kuantitatif). Penentuan sample dalam penelitian kualitatif tidak didasarkan perhitungan statistik. Sample yang dipilih berfungsi untuk mendapatkan informasi yang maksimum, bukan untuk digeneralisasikan.

Jadi, penentuan sample dalam penelitian kualitatif dilakukan saat peneliti mulai memasuki lapangan dan selama penelitian berlangsung (emergent sampling design). Caranya yaitu, peneliti memilih orang tertentu yang dipertim-bangkan dan memberikan data yang diperlukan, selanjutnya berdasarkan data atau informasi yang diperoleh dari sampel sebelumnya itu, peneliti dapat menetapkan sample lainnya yang diper-timbangkan akan memberikan data lebih lengkap.

Penelitian ini akan menggunakan metode analisis data deskriptif kualitatif dengan menggunakan model analisis interaktif (interactive modelanalysis).

Ada 3 (tiga) komponen yang benar-benar harus diperhatikan dalam melakukan metode analisis data deskriptif kualitatif dengan model analisis interaktif tersebut, yaitu:

a. Reduksi Data

Reduksi data merupakan suatu langkah untuk memisahkan hal-hal yang penting dan tidak penting dari data-data yang terkumpul, sehingga nantinya data-data tersebut menjadi lebih focus terhadap tujuan penelitian.

b. Sajian Data

Sajian data merupakan langkah yang dilakukan dengan membuat perencanaan kolom dalam bentuk matriks gambar (skema) dan tabel bagi data kualitatif dalam bentuk khususnya.

c. Penarikan Kesimpulan

Penarikan kesimpulan merupakan langkah terakhir yang dilakukan setelah seluruh proses analisis data telah selesai dilakukan, sehingga akan diperoleh suatu kesimpulan yang tepat dari hasil penelitian yang dilakukan (Lexy J Moleong2006:288).

\section{HASIL DAN PEMBAHASAN}

\section{Hasil Penelitian}

Berdasarkan data yang diperoleh dari hasil wawancara pada Direktorat pendaftaran dan Pemeriksaan LHKPN sebagai berikut:

\section{a. Tingkat Kepatuhan Pelaporan LHKPN Instansi Daerah Tahun 2016-2017}


Tabel 1: Ikhtisar Kepatuhan LHKPN di Lingkup Instansi Daerah Tahun 2016

\begin{tabular}{|l|c|c|c|c|}
\hline Bidang & $\begin{array}{c}\text { Wajib } \\
\text { Lapor }\end{array}$ & $\begin{array}{c}\text { Sudah } \\
\text { Lapor }\end{array}$ & $\begin{array}{c}\text { Belum } \\
\text { Lapor }\end{array}$ & $\begin{array}{c}\text { Kepatuhan } \\
\text { (\%) }\end{array}$ \\
\hline Eksekutif & 98.942 & 63.882 & 35.060 & $64,57 \%$ \\
\hline Legislatif & 12.344 & 3.595 & 8.749 & $29,12 \%$ \\
\hline BUMD & 6.338 & 4.675 & 1.663 & $73,76 \%$ \\
\hline Total & $\mathbf{1 1 7 . 6 2 4}$ & $\mathbf{7 2 . 1 5 2}$ & $\mathbf{4 5 . 4 7 2}$ & $\mathbf{6 1 , 3 4 \%}$ \\
\hline
\end{tabular}

Sumber : Data Direktorat PP LHKPN Tahun 2016

Berdasarkan tabel dan gambar diatas Tingkat Kepatuhan penyampaian LHKPN di Lingkup Instansi Daerah Tahun 2016 total prosentase Sebesar 61,34\%.

Grafik 2: Ikhtisar Kepatuhan LHKPN di Lingkup Instansi Daerah Tahun 2016

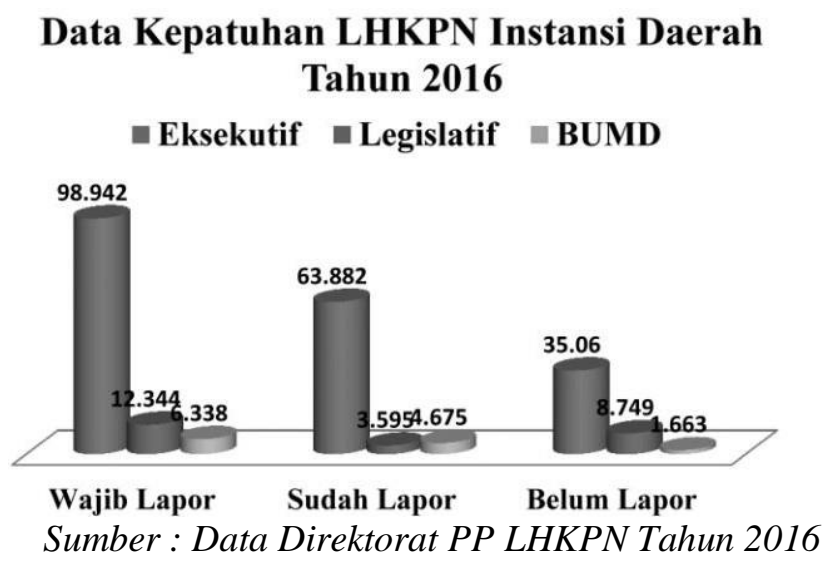

Bahwa kepatuhan penyampain LHKPN Tahun 2016 masih dalam kriteria cukup. Prosentase tersebut masih bisa naik apabila didukung dengan adanya peran serta kesadaran Wajib Lapor untuk melaporkan harta kekayaannya dan Komitmen Kepala Daerah/Pimpinan Instansi terkait penerapan sanksi bagi wajib lapor yang tidak melaporkan LHKPN pada KPK. Kesadaran Wajib Lapor dan Komitmen Kepala Daerah/ Pimpinan Instansi serta pelayanan yang baik dari UPL Instansi dan UPL di Direktorat PP LHKPN akan sangat membantu terhadap tingkat kepatuhan para Wajib Lapor LHKPN sehingga apa yang diharapkan dapat terealisasi dengan baik. 
Tabel 2. Ikhtisar Kepatuhan LHKPN di Lingkup Instansi Daerah 2017

\begin{tabular}{|l|c|c|c|c|}
\hline Bidang & $\begin{array}{c}\text { Wajib } \\
\text { Lapor }\end{array}$ & $\begin{array}{c}\text { Sudah } \\
\text { Lapor }\end{array}$ & $\begin{array}{c}\text { Belum } \\
\text { Lapor }\end{array}$ & $\begin{array}{c}\text { Kepatuhan } \\
(\%)\end{array}$ \\
\hline Eksekutif & 116.612 & 66.741 & 49.871 & $57,23 \%$ \\
\hline Legislatif & 15.198 & 3.362 & 11.836 & $22,12 \%$ \\
\hline BUMD & 6.034 & 1.989 & 4.045 & $32,96 \%$ \\
\hline Total & $\mathbf{1 3 7 . 8 4 4}$ & $\mathbf{7 2 . 0 9 2}$ & $\mathbf{6 5 . 7 5 2}$ & $\mathbf{5 2 , 3 0 \%}$ \\
\hline
\end{tabular}

Sumber : Data Direktorat PP LHKPN Tahun 2017

Grafik 3. Ikhtisar Kepatuhan LHKPN di Lingkup Instansi Daerah

\section{Data Kepatuhan LHKPN Instansi Daerah}

Tahun 2017

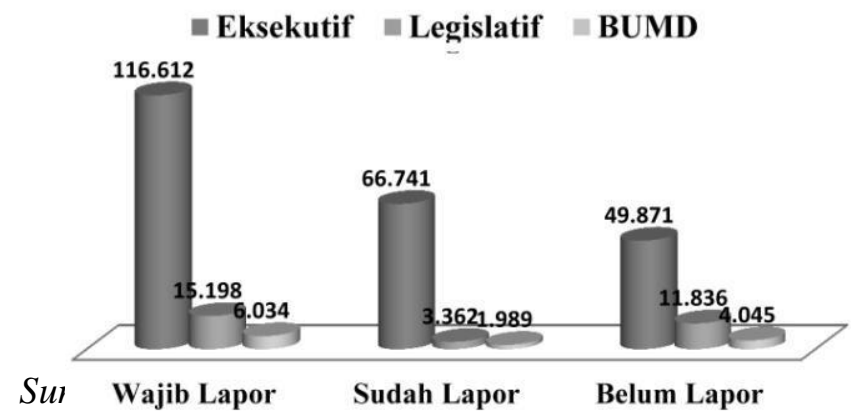

Berdasarkan tabel dan gambar diatas Tingkat Kepatuhan penyampaian LHKPN di Lingkup Instansi Daerah Tahun 2017 total prosentase sebesar 52,30\%. Prosentase ini menunjukan bahwa kepatuhan penyampaian LHKPN ada penurunan dari data yang diperoleh Tahun 2016 dikarenakan ada beberapa Wajib Lapor yang sudah pensiun, meninggal serta perubahan regulasi wajib lapor yang ada dimasing-masing Instansi Daerah.

b. Upaya-upaya yang dilakukan dalam Peningkatan Kepatuhan Pelaporan LHKPN di Lingkup Instansi Daerah

Berdasarkan hasil wawancara dengan Direktorat PP LHKPN yang terlibat langsung dengan kegiatan pelaporan LHKPN maka didapat beberapa upaya yang dilakukan untuk meningkatkan kepatuhan pelaporan LHKPN antara lain sebagai berikut:

1. Berkorespondensi ke pimpinan Instansi Daerah perihal mengeluarkan Surat Keputusan 


\section{JURNAL EKOBIS: EKONOMI, BISNIS \& MANAJEMEN}

Volume 8 Nomor 2 (2018)

mengenai penetapan Wajib LHKPN yang jabatannya dipandang strategis dan rawan KKN, penerapan sanksi ketidakpatuhan dalam memenuhi kewajiban LHKPN di lingkungan Pemerintah Daerah berupa sanksi administratif sesuai peraturan perundang-undangan yang berlaku dan pengeluarkan Surat Keputusan mengenai penunjukan unit pengelola LHKPN untuk mendukung kelancaran kegiatan pengelolaan LHKPN di lingkungan Pemerintah Daerah Provinsi/Kabupaten/Kota.

2. Melakukan koordinasi antara UPL yang ada dimasing-masing instansi dengan pengelola LHKPN yang ada pada Direktorat PP LHKPN, koordinasi dilakukan untuk mengingatkan Wajib LHKPN di lingkungan pemerintah daerah serta Direksi, Komisaris dan Pejabat Struktural lainnya dilingkungan BUMD untuk memenuhi kewajiban penyampaian dan pengumuman LHKPN dan berkoordinasi secara berkala dengan Inspektorat Daerah mengenai kepatuhan Wajib LHKPN serta Direksi, Komisaris dan pejabat struktural lainnya dalam menyampaikan LHKPN kepada KPK.

Selain itu untuk UPL kami melakukan Training of Trainers (ToT) LHKPN dan Bimtek secara aplikasi sehingga para UPL agar memiliki kemampuan dalam penggunaan Aplikasi e-LHKPN.

3. Melakukan Sosialisasi secara berkala untuk PN/ Wajib Lapor LHKPN perihal penjelasan Regulasi dan tata cara pelaporan LHKPN.

4. Melakukan Bimbingan Teknis (Bimtek) LHKPN yaitu lebih memberikan pelatihan bagaimana cara mengisi pelaporan harta pada Aplikasi e-LHKPN.

5. Melakukan pendampingan pengisian pelaporan e-LHKPN dan membuka Klinik LHKPN pada Instansi, lebih memfasilitasi PN/ Wajib Lapor secara personal dalam hal mengalami kesulitan pengisian pelaporan e-LHKPN.

\section{Faktor pendukung dan penghambat dalam pelaksanaan peningkatan kepatuhan pela-} poran LHKPN dilingkup Instansi Daerah

1. Kurang kesadaran dan pemahaman Wajib Lapor terhadap penyampaian pelaporan LHKPN yaitu pelaporan harta kekayaan merupakan salah satu tugas dan fungsi pencegahan korupsi dengan self assessment system yaitu memberikan wewenang, kepercayaan, tanggung jawab kepada wajib lapor untuk mulai mencatatkan, menghitung, memperhitungkan dan melaporkan sendiri harta yang dimiliki dari sebelum, selama dan sesudah menjabat. Self assessment juga dapat membiasakan diri untuk jujur dan bertanggung jawab atas harta yang dilaporkan.

2. Regulasi LHKPN yang belum dikeluarkan oleh pimpinan Instansi yang mengatur Wajib LHKPN dan penerapan sanksinya, jika pimpinan instansi peduli atau komitmen terhadap program pencegahan korupsi salah satunya terkait pelaporan LHKPN sangat membantu dalam tingkat kepatuhan pelaporan LHKPN.

3. Sarana dan prasarana yang masih kurang dalam memfasilitasi pelaporan e-LHKPN pada Instansi daerah, jika sarana dan prasarana sudah memadai akan membantu proses kegiatan, 


\section{JURNAL EKOBIS: EKONOMI, BISNIS \& MANAJEMEN}

Volume 8 Nomor 2 (2018)

sehingga tujuan dari kegiatan tersebut dapat tercapai secara optimal.

4. Peran Aparat Pengawasan Intern Pemerintah (APIP) yang belum maksimal pada Inspektorat Provinsi/Kabupaten/Kota. Perwujudan peran APIP yang efektif yaitu monitoring dan evaluasi terkait penerapan sanksi pelaporan LHKPN sesuai regulasi yang sudah dibuat oleh Instansi Daerah masing-masing.

5. Kurangnya sumber daya manusia dibidang Informasi Teknologi, pelaporan LHKPN sekarang ini menggunakan sistem online tidak bisa dipungkuri para wajib lapor membutuhkan Unit pengelola LHKPN yang ahli dibidang informatika karena sangat membantu kelancaran pengisian pelaporan e-LHKPN bagi Wajib Lapor. Selain itu bisa membantu validasi data wajib lapor dan menyiapkan e-Reporting untuk pimpinan instansi daerah masing-masing.

d. Hasil yang telah dilakukan dalam rangka Peningkatan Kepatuhan Pelaporan LHKPN di lingkup Instansi Daerah

Berdasarkan data dan hasil wawancara dari upaya yang sudah dilakukan dalam rangka peningkatan kepatuhan pelaporan LHKPN di lingkup Instansi Daerah masih kurang memuaskan karena tingkat kepatuhan pelaporan di lingkup Instansi Daerah yang masih cukup rendah serta komitmen pimpinan instansi dalam mengeluarkan regulasi masih sedikit dan penerapan sanksi belum berjalan. Sehingga dalam rangka peningkatan pelaporan LHKPN dibutuhkan komitmen pimpinan instansi daerah untuk mengeluarkan Regulasi terkait Wajib Lapor LHKPN dan implementasi sanksinya serta peran serta UPL Instansi sangat membantu kerja Direktorat PP LHKPN dalam hal pemuktahiran data wajib LHKPN.

e. Tingkat Kepatuhan Pelaporan LHKPN Pemerintah Provinsi Kepulauan Bangka Beitung Tahun 2016-2017

Tabel 3. Rekapitulasi Penyampaian LHKPN di Pemerintah Provinsi Kepulauan Bangka Belitung Tahun 2016

\begin{tabular}{|l|c|c|c|c|c|}
\hline \multicolumn{1}{|c|}{ INSTANSI } & $\begin{array}{r}\text { WAJIB } \\
\text { LAPOR } \\
\text { LHKPN }\end{array}$ & \multicolumn{2}{|c|}{$\begin{array}{c}\text { SUDAH LAPOR } \\
*\end{array}$} & \multicolumn{2}{|c|}{$\begin{array}{l}\text { BELUM } \\
\text { LAPOR }\end{array}$} \\
\hline $\begin{array}{l}\text { PEMERINTAH } \\
\text { PROVINSI KEPULAUAN } \\
\text { BANGKA BELITUNG }\end{array}$ & 123 & 119 & $\mathbf{9 6 , 7 5 \%}$ & $\mathbf{4}$ & $\mathbf{3 , 2 5 \%}$ \\
\hline
\end{tabular}

Sumber : Data Direktorat PP LHKPN Tahun 2016 


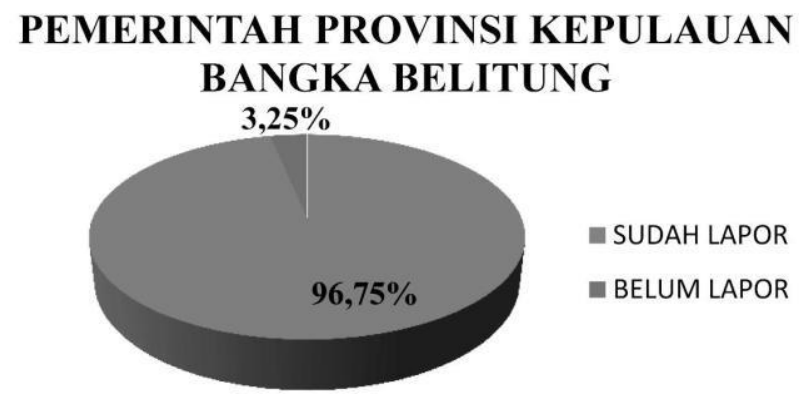

Sumber : Data Direktorat PP LHKPN Tahun 2016

Tabel 4. Rekapitulasi Penyampaian LHKPN di Pemerintah Provinsi Kepulauan Bangka Belitung Tahun 2017

\begin{tabular}{|l|c|c|c|c|c|}
\hline \multicolumn{1}{|c|}{ INSTANSI } & $\begin{array}{l}\text { WAJIB } \\
\text { LAPOR } \\
\text { LHKPN }\end{array}$ & \multicolumn{2}{|l|}{ SUDAH LAPOR *) } & \multicolumn{2}{|c|}{$\begin{array}{l}\text { BELUM } \\
\text { LAPOR }\end{array}$} \\
\hline $\begin{array}{l}\text { PEMERINTAH } \\
\begin{array}{l}\text { PROVINSI } \\
\text { KEPULAUAN } \\
\text { BANGKA BELITUNG }\end{array}\end{array}$ & 239 & 239 & $100,00 \%$ & 0 & $0,00 \%$ \\
\hline
\end{tabular}

Sumber : Data Direktorat PP LHKPN Tahun 2017

Grafik 5: Rekapitulasi Penyampaian

LHKPN di Pemerintah Provinsi Kepulauan Bangka Belitung Tahun 2017

\section{PEMERINTAH PROVINSI KEPULAUAN \\ BANGKA BELITUNG}

-SUDAH LAPOR $\square$ BELUM LAPOR

$0 \%$

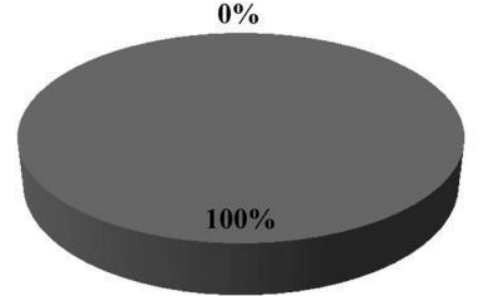

Sumber : Data Direktorat PP LHKPN Tahun 2017 


\section{PEMBAHASAN}

Berdasarkan data dan hasil wawancara, penulis mencoba merinci beberapa Pelaksanaan Peningkatan Kepatuhan Pelaporan LHKPN pada Direkorat Pendaftaran dan Pemeriksaan LHKPN di Lingkup Pemerintah Provinsi Kepulauan Bangka Belitung antara lain:

\section{a. Tingkat Kepatuhan Pelaporan LHKPN di Lingkup Pemerintah Provinsi Kepulauan Bangka Belitung Tahun 2016-2017.}

Berdasarkan tabel dan gambar diatas Tingkat Kepatuhan penyampaian LHKPN di Lingkup Pemerintah Provinsi Kepulauan Bangka Belitung Tahun 2016 total prosentase sudah lapor LHKPN sebesar 96,75\% dan Tahun 2017 total prosentase sudah lapor LHKPN mencapai 100\%. Prosentase ini menunjukan bahwa kepatuhan penyampain LHKPN di Pemerintah Provinsi Kepulauan Bangka Belitung sangat Baik. Karena sejak awal Gubernur Pemerintah Provinsi Kepulauan Bangka Belitung sudah berkomitmen dalam rangka pencegahan korupsi salah satunya dengan mengeluarkan Peraturan Gubernur Kepulauan Bangka Belitung Nomor 56 Tahun 2017 tentang Pengelolaan Laporan Harta Kekayaan Penyelenggara Negara di Lingkungan Pemerintah Provinsi Kepulauan Bangka Belitung. Isi peraturan tersebut memuat siapa saja yang Wajib Lapor LHKPN, bagaimana tata cara penyampaiannya, pengelolaan laporan harta kekayaan Penyelenggara Negara dalam hal ini pembentukan Tim UPL LHKPN Instansi serta memuat sanksi bagi Wajib Lapor yang tidak melaporkan LHKPN mengacu ke PP 53 Tahun 2010 yaitu disiplin tingkat ringan dan sedang.

\section{b. Upaya-upaya yang dilakukan dalam Peningkatan Kepatuhan Pelaporan LHKPN di Lingkup Pemerintah Provinsi Kepulauan Bangka Belitung.}

Tabel 5: Daftar Kegiatan dalam Peningkatan Kepatuhan LHKPN di Pemerintah Pemerintah Provinsi Kepulauan Bangka Belitung

\begin{tabular}{|c|l|}
\hline Tahun & \multicolumn{1}{|c|}{ Kegiatan } \\
\hline 2014 & APP LHKPN \\
\hline 2015 & APP LHKPN \\
\hline 2017 & Sosialisasi UPL dan Bimtek e-Filing \\
\hline 2018 & Rakor LHKPN dan Bimtek e-Filing \\
\hline \multicolumn{2}{|c|}{ Sumber : Data Direktorat PP LHKPN } \\
\hline
\end{tabular}

Direktorat PP LHKPN dari hasil data yang diperoleh tahun 2014 sampai dengan tahun 2018 sudah melakukan beberapa rangkaian kegiatan pendaftaran diantaranya sebagai berikut:

1. Asistensi pengisian dan pengumpulan LHKPN untuk Wajib Lapor LHKPN yaitu kegiatan Bimtek tata cara pelaporan LHKPN sampai dengan mengumpulkan formulir LHKPN pada saat kegiatan. Peraturan terdahulu masih mengacu Kep. KPK Nomor 07/2/2005 pelaporan LHKPN dengan menggunakan formulir Model KPK-A dan Model KPK-B.

2. Sosialisasi LHKPN disini terkait penjelasan Regulasi Wajib Lapor, pembentukan UPL LHKPN dan Monitoring tingkat kepatuhan pelaporan LHKPN. 


\section{JURNAL EKOBIS: EKONOMI, BISNIS \& MANAJEMEN}

\section{Volume 8 Nomor 2 (2018)}

3. Bimtek LHKPN diperuntukan bagi Wajib Lapor agar lebih paham tata cara pelaporan LHKPN dan penggunaan Aplikasi e-LHKPN..

4. Pemberdayaan Sumber Daya Manusia untuk pembentukan UPL dengan memberikan pendidikan dan pelatihan atau semacam Training of Trainers (ToT) LHKPN terkait penggunaan Aplikasi e-LHKPN.

5. Mendorong komitmen Pimpinan terkait pelaksanaan pelaporan LHKPN dengan mengeluarkan regulasi instansi dan penerapan sanksi bagi wajib lapor yang tidak melaporkan LHKPN.

6. Berkoordinasi secara berkala dengan Inspektur Daerah untuk melakukan pemantauan terhadap kepatuhan Pelaporan LHKPN kepada KPK.

c. Faktor pendukung dan penghambat dalam pelaksanaan peningkatan kepatuhan pelaporan LHKPN dilingkup Pemerintah Provinsi Kepulauan Bangka Belitung

1. Kepala Daerah Pemerintah Provinsi Kepulauan Bangka Belitung mengeluarkan Surat Edaran Nomor: 840/0098/VII/2018 pertanggal 3 April 2018 tentang penundaan pembayaran Tunjangan Perbaikan Penghasilan (TPP). Bagi Wajib Lapor yang belum mengisi dan menyerahkan pelaporan LHKPN.

2. Pembentukan Tim UPL di Pemerintah Provinsi Kepulauan Bangka Belitung untuk berkoordinasi dengan KPK mengenai kegiatan pengelolaan LHKPN dilingkungan Instansinya, seperti pemuktakhiran data kepegawaian wajib LHKPN pada Aplikasi eLHKPN.

3. Terkait perubahan Per.KPK Nomor 07 tahun 2016 tentang Tata cara Pendaftaran dan Pemeriksaan Harta Kekayaan Penyelenggara Negara ada beberapa Wajib Lapor

yang masih awam dalam menggunakan Aplikasi e-LHKPN.

d. Hasil yang telah dilakukan dalam rangka Peningkatan Kepatuhan Pelaporan LHKPN di Provinsi Kepulauan Bangka Belitung

Dari hasil wawancara Direktorat PP LHKPN setelah dilakukan beberapa kegiatan sebagai penunjang tingkat kepatuhan pelaporan LHKPN serta komitmen Kepala Daerah dalam penerapan sanksi bagi wajib lapor yang tidak melaporkan LHKPN. Hasilnya Tingkat Kepatuhan Pelaporan LHKPN di Pemerintah Provinsi Kepulauan Bangka Belitung tahun 2017 mencapai $100 \%$.

\section{PENUTUP}

Setelah melaksanakan penelitian di Direktorat Pendaftaran dan Pemeriksaan LHKPN penulis menarik kesimpulan sebagai berikut:

a. Presentase tingkat Kepatuhan Pelaporan LHKPN di Lingkup Instansi Daerah pada tahun 2016 sebesar 61,34\% masuk dalam kriteria cukup, tahun 2017 sebesar 52,30\% masuk dalam kriteria rendah. Persentase tersebut mengalami penurunan sebesar $9,04 \%$. Prosentase tersebut masih bisa naik apabila didukung dengan adanya peran serta kesadaran Wajib Lapor untuk melaporkan harta kekayaannya dan komitmen Kepala Daerah/ Pimpinan Instansi terkait penerapan sanksi bagi wajib lapor yang tidak melaporkan 


\section{JURNAL EKOBIS: EKONOMI, BISNIS \& MANAJEMEN}

\section{Volume 8 Nomor 2 (2018)}

LHKPN pada KPK. Kesadaran Wajib Lapor dan Komitmen Kepala Daerah/Pimpinan Instansi serta pelayanan yang baik dari UPL Instansi dan UPL di Direktorat PP LHKPN akan sangat membantu terhadap tingkat kepatuhan para Wajib Lapor LHKPN sehingga apa yang diharapkan dapat terealisasi dengan baik.

b. Presentase tingkat Kepatuhan Pelaporan LHKPN di Lingkup Pemerintah Provinsi Kepulauan Bangka Belitung pada tahun 2016 sebesar 96,75\% dan tahun 2017 sebesar $100 \%$ persentase paling tinggi. Persentase tersebut mengalami kenaikan sebesar 3,25\%. Karena sejak awal Gubernur Pemerintah Provinsi Kepulauan Bangka Belitung sudah berkomitmen dalam rangka pencegahan korupsi salah satunya dengan pelaporan LHKPN dan mengeluarkan Peraturan Gubernur Kepulauan Bangka Belitung Nomor 56 Tahun 2017 tentang Pengelolaan Laporan Harta Kekayaan Penyelenggara Negara di Lingkungan Pemerintah Provinsi Kepulauan Bangka Belitung serta mengeluarkan Surat Edaran Nomor: 840/0098/VII/2018 pertanggal 3 April 2018 tentang penundaan pembayaran Tunjangan Perbaikan Penghasilan (TPP). Bagi Wajib Lapor yang belum mengisi dan menyerahkan pelaporan LHKPN.

a. Upaya-upaya yang dilakukan dalam Peningkatan Kepatuhan Pelaporan LHKPN di Lingkup Instansi Daerah dan di Lingkup Pemerintah Provinsi Kepulauan Bangka Belitung melakukan Sosialisasi, Bimtek e-LHKPN dan pendampingan pengisian e-LHKPN, berkoordinasi secara berkala dengan Inspektur Daerah untuk melakukan pemantauan terhadap kepatuhan Pelaporan LHKPN kepada KPK dan Mendorong komitmen Pimpinan Instansi terkait pelaksanaan pelaporan LHKPN dengan mengeluarkan regulasi instansi dan penerapan sanksi bagi wajib lapor yang tidak melaporkan LHKPN.

b. Faktor pendukung dan penghambat dalam pelaksanaan peningkatan kepatuhan pelaporan LHKPN dilingkup Instansi Daerah dan Pemerintah Provinsi Kepulauan Bangka Belitung yaitu komitmen Pimpinan Instansi terkait pelaksanaan pelaporan LHKPN dengan mengeluarkan regulasi instansi dan penerapan sanksi bagi wajib lapor yang tidak melaporkan LHKPN. Perubahan Per.KPK Nomor 07 tahun 2016 tentang Tata cara Pendaftaran dan Pemeriksaan Harta Kekayaan Penyelenggara Negara ada beberapa Wajib Lapor yang masih kurang familiar dalam menggunakan Aplikasi e-LHKPN. Pemberian sanksi seperti penundaan TPP dapat membantu dalam hal pelaksanaan peningkatan kepatuhan pelaporan LHKPN Sehingga bisa sebagai benchmarking untuk Instansi Daerah lainnya yang masih rendah tingkat kepatuhannya.

Dari pembahasan dan kesimpulan yang telah disampaikan, penulis dapat memberikan masukan dan saran dalam rangka peningkatan kepatuhan pelaporan LHKPN pada tahun yang akan mendatang sebagai berikut:

a. Mendorong komitmen Pimpinan Instansi Daerah untuk mengeluarkan peraturan tentang pengelolaan Laporan Harta Kekayaan Penyelenggara Negara serta pencantuman sanksi contohnya seperti penundaan TPP bagi Wajib Lapor yang tidak melakukan pelaporan LHKPN sangat membantu peningkatan Kepatuhan pelaporan LHKPN.

b. Koordinasi secara berkala dengan Koordinator LHKPN di level top manajemen dan anggota UPL dalam rangka monitoring kepatuhan pelaporan LHKPN di utamakan bagi Instansi Daerah yang tingkat kepatuhannya masih sangat rendah. 


\section{JURNAL EKOBIS: EKONOMI, BISNIS \& MANAJEMEN}

\section{Volume 8 Nomor 2 (2018)}

c. Mendorong agar peran APIP lebih optimal dalam melakukan monitoring dan evaluasi bagi Wajib Lapor yang tidak melaporkan LHKPN.

d. Melaksanakan Pendidikan dan Pelatihan SDM antara lain:

1) Training of Trainers (ToT) LHKPN untuk UPL Instansi dalam penggunaan Aplikasi e- Registration dan e-filing pada Aplikasi e- LHKPN di utamakan bagi Instansi Daerah yang tingkat kepatuhannya sangat rendah.

2) Sosialisasi dan Bimtek Aplikasi e-LHKPN untuk Wajib Lapor pada Instansi Daerah yang tingkat kepatuhannnya sangat rendah.

\section{REFERENSI}

Komisi Pemberantasan Korupsi Republik Indonesia. (2016). Surat Edaran Nomor SE-08/01/10/ 2016 tentang Petunjuk Teknis Penyampaian dan Pengelolaan Laporan Harta Penyelenggara Negara setelah Diberlakukannya Peraturan Komisi Pemberantasan Korupsi Nomor 07 Tahun 2016 tentang Tata Cara Pendaftaran, Pengumuman, dan Pemeriksaan Harta Kekayaan Penyelenggara Negara. Jakarta: Komisi Pemberantasan Korupsi Republik Indonesia.

Lexy J. Moleong, (2008), Metodologi Penelitian Kualitatif. Bandung: Remaja Rosda Karya. Taylor (2014), Psikologi Sosial. Jakarta: Erlangga.

Shaw (2010), The Psylogy of Small Group Behaviour. New Delhi Mc Grow Hill Publishing Company Ltd.

Republik Indonesia. 1999. Undang-Undang Nomor 28 Tahun 1999 tentang Penyelenggara Negara yang Bersih dan Bebas dari Korupsi, Kolusi dan Nepotisme.

Republik Indonesia. 2016. Peraturan Gubenur Kepulauan Bangka Beliung Nomor 56 Tahun 2016 tentang Pengelolaan Laporan Harta Kekayaan Penyelenggara Negara di Lingkungan Pemerintah Provinsi Kepulauan Bangka Belitung. 